\title{
Structure Design of Support Frame of Cableway on Car for Emergency Repair
}

\author{
PENG Fei, JIANG Ming, LIU Kai, ZHAO Fei
}

China Electric Power Research Institute, Beijing 100055, China

Pengfei_seu@163.com

Keywords: Support Frame, Cableway, Structure design

Abstract. The cableway on car for emergency repair has the characteristics of rapid, efficient and flexible etc., which can meet the requirement of power grid's emergency repair, this article mainly through force calculation of beam and pillar of support frame, completed the structure design of the support frame of cableway on Car emergency repairs.

\section{Introduction}

Due to overhead transmission lines often through the mountains, the problem of construction transportation largely determines the efficiency of power grid's emergency repair. Currently the degree of mechanization of overhead transmission lines is not high in our country, in the construction area where the vehicle transportation is inconvenient, often rely on human to transport, while cableway transportation just needs to put up ropes, and we can transport the construction materials and tools to the designated locations from the air directly. Considering the perspective of repair economy, repair efficiency and repair quality, using car cableway transports construction equipment is the most optimal solution.

The overall design scheme: Set the end support frame in the mountains and so on which are higher-lying, set the initial support frame in low-lying, flat areas. In order to achieve the efficiency of emergency repairs, the initial support frame is mounted on a car which can move, while the car is configured with a motor-driven winch, providing ample power for traction of the cable, the other end of the cable will be connected to the end support frame, forming a complete lifts. We can use the movable car transport materials between the initial support frame and the end support frame, the total design scheme shown in Figure 1.

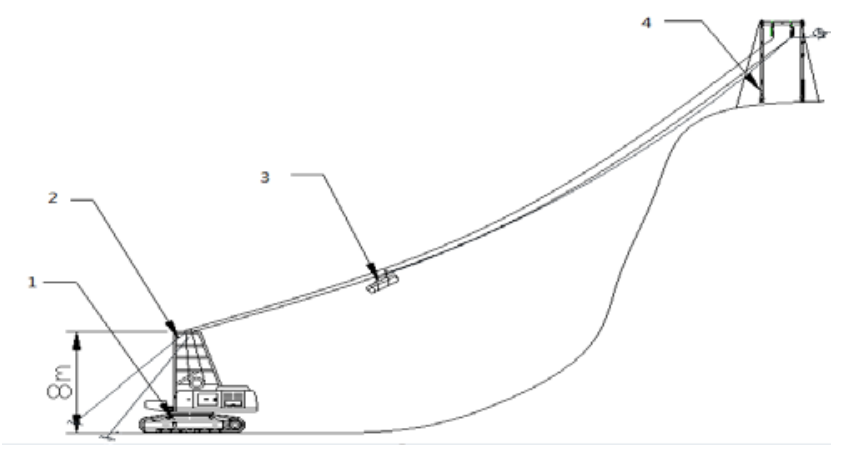

Fig.1: Cableway on car for power grid's emergency repair

\section{Structure design of the Support frame}

In order to meet various terrain conditions in the construction site, the height of support frame and length of each pillar can be adjusted flexibly. Thus, the pillar uses standard modular section, and is equipped with the bottom trimming adjustment device. At the construction site, the height of pillar can be adjusted according to the different height of cableway and the undulation of terrain. The method of adjustment include: (1) each pillar of support frame can adjust by adding or reducing 
the standard section, the minimum length of the standard section is $1 \mathrm{~m}$; (2) each pillar of support frame is equipped with length micro-adjustment device, and can slightly adjust height by the bottom adjustment device. Micro-adjustment device is combined with the inside, the outer sleeves, the tightener and the tightener's shaft, length of the pillar is adjusted by the adjustment device which is connected with the inside, the outer sleeves, and the adjustment device shaft. This solves the problem that the uneven settlement of the pillar may occur during use. the structure of the pillar is shown as Figure 2.

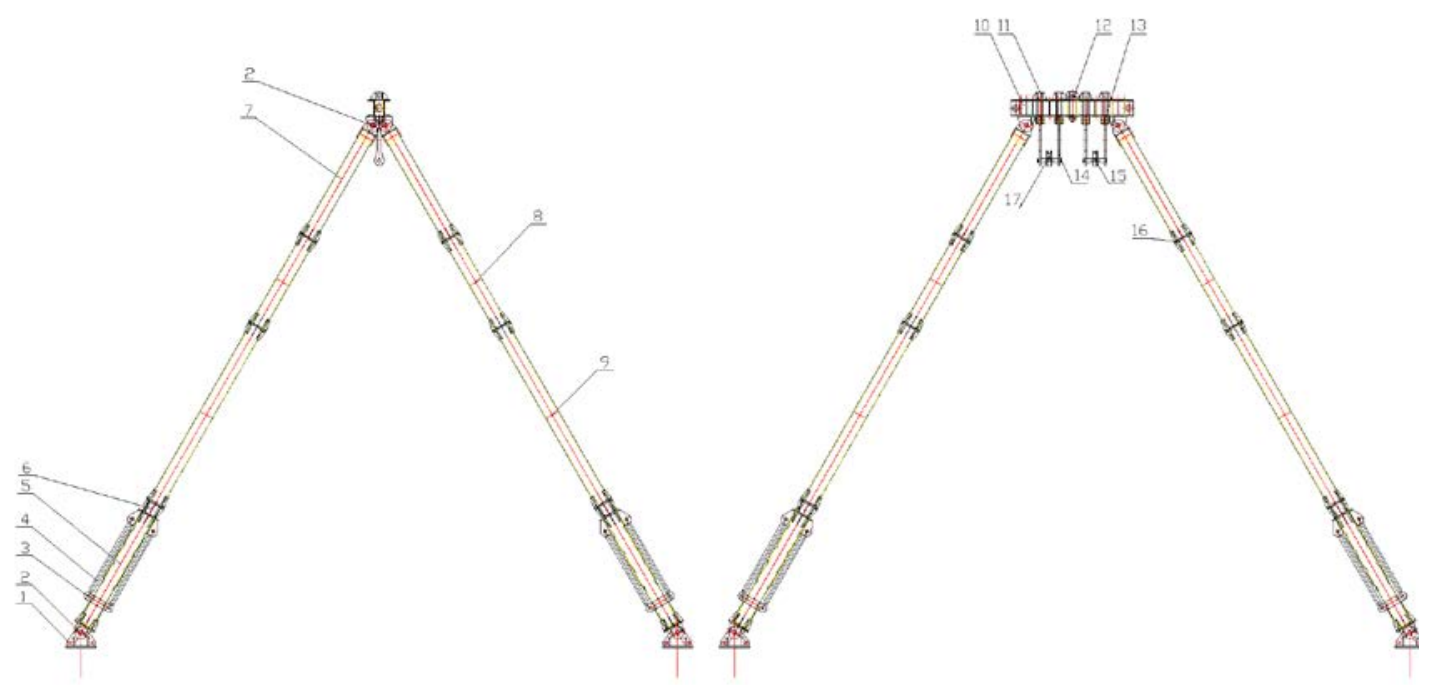

1-base; 2-pins; 3-regulator shaft; 4-tightener; 5-outer sleeve; 6-inner sleeve; 7— top segment; 8-

1m standard section; 9—2m standard section; 10— top beam; 11—drawing board seat; 12—traction rope lug; 13_drawing board top shaft; 14 — drawing board; 15—-the below shaft of the below drawing plate ; 16-bolts (sets); 17-the wheel of propping the cable.

Fig. 2 The structure of the pillar

\section{Calculation of the pressure of the beam}

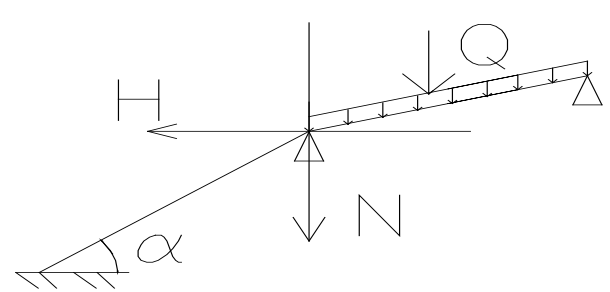

Fig.3 The stress diagram of stent beam

The formulas of calculation of the pressure of the beam:

$$
\begin{gathered}
\mathrm{N}=\frac{G}{2}+Q+\sum H \operatorname{tg} \alpha=\frac{G}{2}+Q+\left(n H_{1} \operatorname{tg} \alpha+2 H_{2} \operatorname{tg} \alpha\right) \\
G=G_{1}+G_{2}+G_{3}=\frac{n_{1} l w_{1}}{\cos \beta}+\frac{n_{2} l w_{2}}{\cos \beta}+\frac{n_{3} l w_{3}}{\cos \beta}
\end{gathered}
$$

$\mathrm{N}$ - total pressure on the beam, $\mathrm{kg}$.

$\mathrm{H}_{1}$ - When the payloads locates the middle of the span(for two-span cableway) or the largest middle of the span of the resistant tension section (for multi-span cableway), the maximum level tension of load cable, kg; take $\mathrm{H}$ bearing=993.4kg;

$\mathrm{H}_{2}$ - the haul cable tension corresponding the maximum level of load cable, kg; $\mathrm{H}$ pull = $981.6 \mathrm{~kg}$

$\mathrm{N}$ - the number of carrying cable, when a single cable: $\mathrm{n}=1$;

$\mathrm{Q}$ - concentrated load weight (including the weight of accessories and rigging), kg; take Q = $600 \mathrm{~kg}$; 
$\mathrm{G}_{1}$ - the total weight of the load cable within the span, kg;

$\mathrm{G}_{2}$ - the total weight of the back empty cable within the span (the same size with load cable), kg;

$\mathrm{G}_{3}$ - the total weight of the pulling cable within the span, kg;

$\mathrm{n}_{1}$ - the number of load cable, for $1000 \mathrm{~kg}, 2000 \mathrm{~kg}$ level cableway, take $\mathrm{n}_{1}=1$;

$\mathrm{n}_{2}$ - the number of return empty cable; for $1000 \mathrm{~kg}$, 2000kg level cableway, take $\mathrm{n}_{2}=1$;

$\mathrm{n}_{3}$ - the number of pulling cable ; take $\mathrm{n}_{3}=2$;

$w_{1}$ - the weight per unit length of load cable, $\mathrm{kg} / \mathrm{m}$; take $=1.4 \mathrm{~kg} / \mathrm{m}$;

$w_{2}$-the weight per unit length of back empty cable, $\mathrm{kg} / \mathrm{m}$; take $=0.69 \mathrm{~kg} / \mathrm{m}$;

$w_{3}$ - the weight per unit length of pulling cable, $\mathrm{kg} / \mathrm{m}$; take $=0.68 \mathrm{~kg} / \mathrm{m}$;

$l$ - the span of the load cable, $\mathrm{m}$; take $\mathrm{l}=600 \mathrm{~m}$;

$\beta$ - the bearing elevation angle between the cable support point; take $\beta=5^{\circ}$

$\alpha$-the angle between the horizontal plane should not be greater than $30^{\circ}$ (bearer cable anchored to the ground), take $\alpha=30^{\circ}$;

$$
\begin{gathered}
G=G_{1}+G_{2}+G_{3}=\frac{n_{1} l w_{1}}{\cos \beta}+\frac{n_{2} l w_{2}}{\cos \beta}+\frac{n_{3} l w_{3}}{\cos \beta} \\
=\frac{600 \times 1.4}{\cos 5^{\circ}}+\frac{600 \times 0.69}{\cos 5^{\circ}}+\frac{2 \times 600 \times 0.68}{\cos 5^{\circ}}=1260 \mathrm{~kg} \\
\mathrm{~N}=\frac{G}{2}+Q+\sum \operatorname{tg} \alpha=\frac{G}{2}+Q+\left(n H_{1} \operatorname{tg} \alpha+2 H_{2} \operatorname{tg} \alpha\right) \\
\frac{1260.2}{2}+600+\left(993.4 \times \operatorname{tg} 30^{\circ}+2 \times 981.6 \times \operatorname{tg} 30^{\circ}\right)=2937.1 \mathrm{~kg}
\end{gathered}
$$

The rated pressure of the beam is $100 \mathrm{kN}$, and now the calculation of pressure is $29.3 \mathrm{kN}$, meets the requirements of 3-fold safety factor.

\section{Calculation of the horizontal force of the beam}

The level unbalanced force P of transom bracket produces primarily by the friction between the saddle of load cable and the rope, we only calculate $f$ - friction.

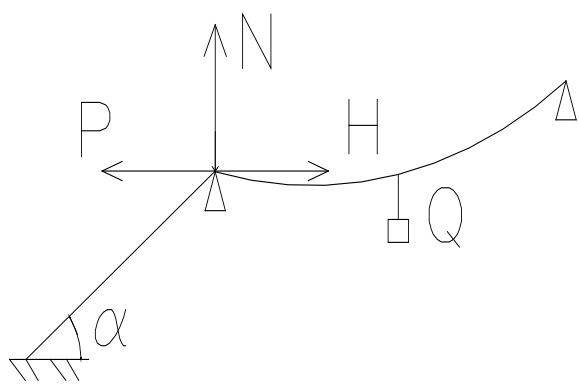

Fig.4 The stress diagram of stent saddle

$$
P=f_{\text {friction }}=N \varepsilon_{\text {friction }}
$$

$\mathrm{p}$ - the horizontal force of beam, kg;

$\mathrm{f}_{\text {friction }}$ - the frictional force generates on the saddle of sent, kg;

$\mathrm{N}$ - the total pressure acting on the beam, kg. Take $\mathrm{N}=2937.1 \mathrm{~kg}$;

$\varepsilon_{\text {friction }}$ - coefficient of friction: 0.15.

\section{Force calculation of herringbone pillar}

The tensile $\mathrm{P}$ of pillar along the bracing wire, which mainly is unbalanced force for balancing beam bracket. 


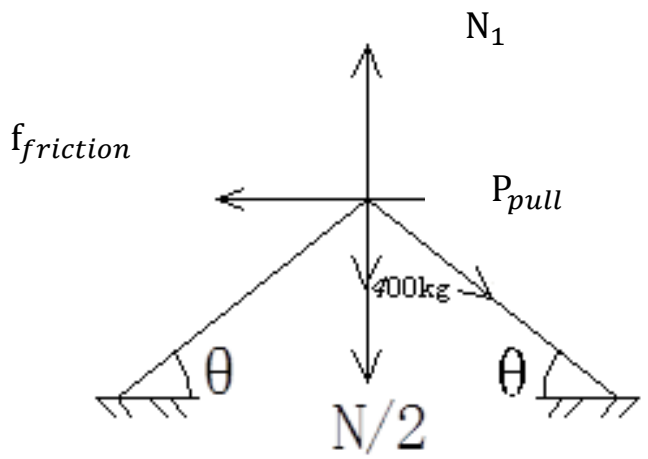

Fig.5 The stress analysis diagram of stent saddle

$\theta$ - the angle between the front and rear cable along the line and ground; take $30^{\circ}$

The pressure $N_{1}$ consists of the pressure generated by pull $\mathrm{P}$ along the line, half of $\mathrm{N}$ and $\mathrm{N}=$ $400 \mathrm{~kg}$, the calculation formula is:

$$
N_{1}=\frac{N}{2}+f \operatorname{tg} \theta+400
$$

$\theta$ - the angle between the front and rear cable along the line and ground; take $30^{\circ}$

The level pull p of door type pillar leg:

$$
N_{1}=\frac{N}{2}+f t g \theta+400=\frac{2937.1}{2}+440.6 \times \operatorname{tg} 30^{\circ}+400=2122.9 \mathrm{~kg}
$$

$\gamma$ - the angle between herringbone pillars, ${ }^{\circ}$;

$N_{1}$ - axis pressure of single herringbone pillar, kg;

The leg is made by $\Phi 108 \times 5$ steel pipes, $6 \mathrm{~m}$ length of it can withstand $80 \mathrm{kN}$, and now the pressure at this pillar leg is $21 \mathrm{kN}$, meets the requirements of 3 times safety factor.

\section{Summary}

This article mainly through force calculation of beam and pillar of support frame, completed the structure design of the support frame of cableway on Car emergency repairs.

\section{References}

[1] Yang Xuechun, Dong Xibin. Design on Foundation Type of Passenger Cableway. Journal of Northeast Forestry University.2008-12.

[2] Q/GDW 118-2014 Construction technology guide of special aerial material ropeway for over transmission line .

[3] SUN Zhusen, MIAO Qian., JIANG Ming . Standardized Construction Scheme for Aerial Ropeway of Electric Transmission Line Engineering. Electric Power Consruction.2011-3.

[4] MIAO Qian,BAI Xue-song. Study on Transportation Technology and Equipment in Freight Cableway System[J].Electric Power Construction.2009(12)

[5] BAI Xue-song, MIAO Qian. Discussion about Working Cable Selection and Design for Construction Cargo Cableway[J]. Electric Power Construction. 2007(08) 